\title{
Ethnobotanical Surveys of Plants Lactogens Properties of the African Pharmacopoeia (Ivory Coast): Study of the Biotolerance in Wistar Rats
}

\author{
Adepo Y. P ${ }^{1}$, Dally T2 ${ }^{2}$ Amonkan K. A \\ ${ }^{1}$ Laboratory of Biochemistry and Food Science, Faculty of Biosciences Félix Houphouët-Boigny University, Abidjan (Ivory Coast) \\ ${ }^{2}$ Pedagogical Unit of Animal Physiology, Nutrition, Faculty of Environment, University Jean Lorougnon Guede, Daloa \\ ${ }^{3}$ Laboratoire de nutrition et de pharmacologie, UFR Biosciences Université Félix Houphouët-Boigny, Abidjan (Ivory Coast)
}

\begin{abstract}
Ethnobotanical surveys, conservation of plants from shredded ethnobotanical surveys and the effects of plant tolerance on mature rats of Wistar strain were conducted. The aim is to identify the lactogens plants with extensive use associated with a method of preserving plant lactogens homogenates would be more appropriate in rural areas and to address possible side effects on the body. The results indicate the existence of plants with lactogens emergence of high frequencies, with a method of preserving plant regrind up to 90 days for the plants to dry. On the effects of plant tolerance, the results of plasma concentrations such as glutamic oxaloacétiques transaminases, glutamic pyruvic transaminase, urea and creatinine show the possibility of using the Euphorbia hirta plant.
\end{abstract}

Keywords: ethnobotanical investigation, Euphorbia hirta, Secamone afzelii, biotolerance rats

\section{Introduction}

The plants of the African pharmacopoeia are generally used as therapeutics [4]. Among these therapeutics, pride of place is given to the use of lactogens plants. Several authors have conducted scientific work on African plants known stimulate lactation. Some authors have shown that plants administered orally are capable of inducing the synthesis of milk of rats [15]. In Ivory Coast, the surveys carried out in some neighborhoods of Abidjan, revealed that $90 \%$ of mothers gave more of artificial milk breast milk to their infants under four months [6]. In addition, insufficient increase breast feeding resulted in infants, the fragility of the body and a mortality rate of $80 \%$ among children under one year [6]. Medicinal plants are generally more prevalent in the southern area of the Ivory Coast on the edge of the savannah [24]. This geographical dispersion of medicinal plants of the Ivorian flora guided our choice on the southern resorts of the Ivory Coast, where the need for an ethnobotanical survey to identify lactogens plants. In Ivory Coast, traditional medicine has an important place in the treatment of various diseases [2]. But ignorance of the toxicological properties of the plants used in traditional medicine, expose people to the real risks of therapeutic accidents that can sometimes be tragic [23].This study is part of an African pharmacopoeia development program in general and in particular Ivorian. It is in this work to list the property planted lactogen used by women to stimulate lactation and study the bio-tolerance of two of them (Euphorbia hirta and Secamone afzelii).

\section{Material and Methods}

\subsection{Investigation}

\subsubsection{Study environment}

The ethnobotanical survey of plants lactogen property was conducted among populations of ten localities of the country namely in general in the South of the Ivory coast; 5 places in the city of Abidjan and 5 other localities of the interior in case Anyama, Akoupé, Aboisso, Bingerville, Jacqueville and Abidjan (Abobo, Adjamé, Treichville, Marcory, Port-Bouet). Abidjan, Jacqueville are in the region of large bridges. The town of Aboisso is part of the South Comoé region while the towns of Akoupé and Anyama are from the region of Agnébi Tiassa .

\subsubsection{Media studies}

This part of our study does not require any measurement. It includes collections of sufficient information through surveys of a target population of the ten areas of study. The information collected have been following some availability because of the sensitivity of the subject for young children which closely related topic breast milk. So we used essentially designed a survey sheet taking into account the objectives set.

\subsubsection{Animal material}

The animal material is composed of strain adult Wistar rats (Rattus norvegicus). 14 week preselected by the fourth week to avoid mating. The conditions of keeping and feeding are carried out according to the standards [5]. Indeed rats constantly receive the food and the temperature is between $25^{\circ} \mathrm{C}$ and $35^{\circ} \mathrm{C} .18$ adult rats body weight average $255 \pm 5 \mathrm{~g}$ were divided into 3 groups of 6 rats at the pet University Félix Houphouët-Boigny.

\subsubsection{Rootstock}

The plant material, identified in the National University Floristic Center Félix Houphouët-Boigny by Professor AKE A. L. consists of the aerial part of the plant Euphorbia hirta L. (Euphorbiaceae) at number $00575846 \mathrm{P}$ according to the National Herbarium of Paris and Secamone afzelii (Schult) K. Schum (Asclepiadaceae) to 120801 specimen number (herbarium Gabon). 


\section{International Journal of Science and Research (IJSR)}

ISSN (Online): 2319-7064

Index Copernicus Value (2013): 6.14 | Impact Factor (2015): 6.391

\section{Methods}

\subsection{Survey Methodology}

\subsubsection{Sampling}

The technique used is simple random sampling. The selection of independent individuals is random. The choice of sites and target people for questionnaires ethnobotany survey does not follow any device. Information was collected from traditional healers and women on plants boots sales premises at number 200 in rural and urban areas. Thus, questions were asked in each locality at 20 targets people whose technique has collected individual information.

\subsubsection{Site selection}

Our choice was ten localities including 5 localities of the city of Abidjan and 5 other localities of the Interior in the Anyama case Akoupé, Aboisso, Bingerville, Jacqueville and Abidjan (Abobo, Adjame, Treichville, Marcory, Port Bouet). The questions were related to the possible existence of plants lactogen. They were chosen, in general, based on the existence of the problem of lactation in some neighborhoods of Abidjan area [6]. Also herbal medicines are generally more prevalent in the southern area of the Ivory Coast on the edge of the savannah [2]-[3]-[4]. So this geographical dispersion of medicinal plants of the Ivorian flora has guided us with our choice on the southern resorts of the Côte d'Ivoire for making our ethnobotanical survey.

\subsection{Shredded conservation of the aerial parts of fresh and dry plants}

The aerial parts of the plants fresh and dry ground material is placed in storage at a temperature of $28 \pm 1^{\circ} \mathrm{C}$ between 25 and $35^{\circ} \mathrm{C}$ [26], the principle is to remove the water contained in plants while retaining the active ingredients. In fact, drying is the easiest method of preservation, most economical and most used. Conserved dry plants from fresh plants, dried beforehand in an oven at a temperature of $80^{\circ}$ $\mathrm{C}$ for $72 \mathrm{~h}$. Conservation of medicinal plants used to assess the state of plant that offers a long shelf life and should not exceed 2 years. The conservation criterion is assessed by the change in pigmentation of the affected plants [26].

\subsection{Aqueous Extract Preparation}

The aerial parts of ground dry plants are subjected to an aqueous extraction, with an amount of $100 \mathrm{~g}$ of plant material to 1.51 of distilled water. The whole is heated to $\left(80-90^{\circ} \mathrm{C}\right)$ for 45 minutes. The homogenate cooled for $5 \mathrm{~min}$ is filtered using a small mesh poplin fabric raised a first filtrate and a residue. The resulting residue is added 11 of distilled water and heated to $80^{\circ} \mathrm{C}$ for $30 \mathrm{~min}$ and then filtered to collect also a second filtrate. The second filtrate is added to the first filtrate to form the aqueous extract. It is lyophilized to obtain the lyophilized.

\subsection{Animal Experimentation}

Rats receive vivo extracts orally plants for 4 days using a gavage tube [16]. $1 \mathrm{~g}$ of extract is dissolved in $5 \mathrm{ml}$ of distilled water. Rats receive plant extracts as compared with control groups receiving water. However, batch 3 rats (negative control) receive only distilled water. 18 rats were randomized into 3 lots $(n=6)$.

Table 1: Sampling of experimental rats

\begin{tabular}{|c|c|}
\hline Batchs & Treatments \\
\hline 1 & Aqueous extract of Euphorbia hirta \\
\hline 2 & Aqueous extract of Sécamone afzelii \\
\hline 3 & Negative control (distilled water) \\
\hline
\end{tabular}

The administration of the extracts are in the morning at 8 am and $16 \mathrm{pm}$ in the evening with the body dose 784.10-3g / $\mathrm{ml}$ $/ \mathrm{kg}$. Blood samples of at least $2 \mathrm{ml}$ are performed on an empty stomach in rats immediately after the fourth day of treatment at the jugular vein in dry hemolysis tubes capacity $4 \mathrm{ml}$ just after sacrificing the animals. Dry hemolysis tubes are kept in a cooler containing ice beforehand. The collected blood is centrifuged at $3000 \mathrm{rev} / \mathrm{min}$ for 10 minutes using a Jouan centrifuge. The evaluation of plasma levels of serum parameters is performed on the obtained serum. Evaluation methods in plasma levels of biochemical parameters were carried out according to the manufacturers of the reagent. The results of serum parameters such as glutamic pyruvic transaminase, glutamic oxaloacétiques transaminases, urea [11] and creatinine [1] are analyzed and calculated using a VIDAS type of controller.

\subsubsection{Determining the activity of transaminases glutamic oxaloacétiques}

The determination of plasma levels of transaminases glutamic oxaloacétiques (TGO) is based on the principle of the kinetics of TGO activity (IU/1) [11].

\subsubsection{Determination of glutamic pyruvic transaminase activity}

The determination of plasma levels of glutamic pyruvic transaminase is based on the principle of the kinetics of TGP activity (IU/1) [11].

\subsubsection{Determination of creatinine}

Plasma creatinine concentration $(\mathrm{mg} / \mathrm{l})$ is determined by the kinetic method. Creatinine reacts with picric acid in an alkaline medium to form a complex revealed by a red color orange [11]-[16].

\subsubsection{Determination of uremia}

The plasma concentration of urea $(\mathrm{g} / \mathrm{l})$ is determined by the end point method of urea [11]. Indeed, urea reacts with a complex to form NAD +.

\subsubsection{Statistical analyses}

Sheets investigations were stripped using the Excel Spreadsheet. The collected quantitative data were submitted to a descriptive analysis. Conservation shredded and made animal experiments have collected quantitative data. A test of Newman-Keuls a classification criterion at the 5\% threshold was conducted to evaluate the significant difference in average for the shredded shelf life of fresh and dry plants, in addition to biochemical parameters contents of such values as transaminases glutamic oxaloacetic glutamic pyruvic transaminase urea and creatinine were performed using the software release Statistikat 7.1. Letters (a, b, c, d, e, $\mathrm{f}$..etc) are raised in indices average or above bands 


\section{International Journal of Science and Research (IJSR) \\ ISSN (Online): 2319-7064}

Index Copernicus Value (2013): 6.14 | Impact Factor (2015): 6.391

histograms. The difference in average achieved is significant when the letters are not identical.

\section{Results}

\subsection{Ethnobotanical Surveys}

Since the observations made from traditional healers in both rural and urban areas, on lactogens plants of the African pharmacopoeia, we felt it necessary to review the main results. This survey was conducted for the primary purpose of knowing the existence of plants lactogens properties. The survey was preferentially given to women of childbearing age account breastfeeding problem that can preferentially affected.

\subsubsection{Balance Sheet and Counting}

The results of this analysis in this paper relate to 200 people who agreed to participate fully and completely with the investigation. After counting all the records indicated data were all processed indicated by women.

\subsubsection{Due to the use of Plants to Lactogens Property}

During the investigation two main reasons seems to explain the use of plants to lactogens properties by women. This is the actual existence of the problems of rising milk and relatively cheaper cost of boots of plants that vary from 50 to 100 CFA francs.

\subsubsection{Proportion of emergence plants cleanings lactogens}

The respondent indicates the existence and use of 6 plants lactogens properties. These lactogens plants selected during ethnobotanical surveys, Euphorbia hirta (40\%) and Secamone afzelii (35\%) have high emergences of frequencies (Figure 1).

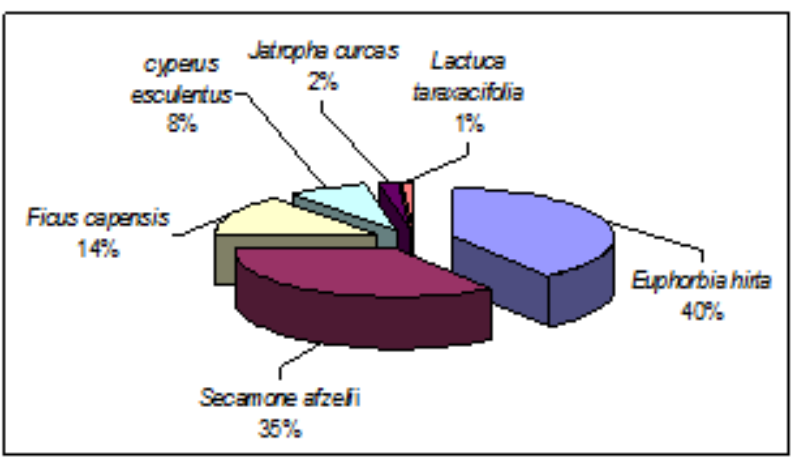

Figure 1: Frequency of emergence lactogens plants obtained during the ethnobotanical surveys

4.1.4 Proportion of people who responded positively to the existence of plants lactogens properties

The respondent states that $95 \%$ of the 200 women interviewed say yes to the existence and use of 6 plants lactogens properties (Figure 2).

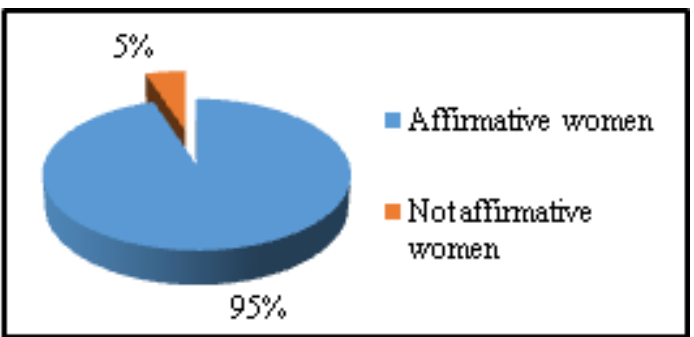

Figure 2: Proportion of women who say the existence of plants lactogens properties

4.1.5 Proportion of women who say the existence of a lactation problems

The ethnobotanical survey was conducted in ten towns and questions on the survey form were administered to women. $60 \%$ of the 200 women interviewed stressed the existence of a difficult climb milk problem in the breasts in nurses. However $40 \%$ of the 200 women have real knowledge possible problems with lactation (Figure 3).

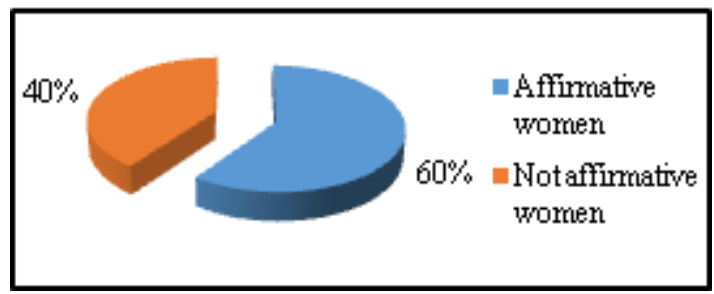

Figure 3: Proportion of women who say the existence of problems related to lactation

\subsubsection{Revenues obtained during investigations}

Traditional practices can relieve nurses who encounter lactation problems. The most used plants for healing by traditional practices are presented as forms of revenue. They are directly administered to nursing mothers, either in pure form or in the form of food accompaniments. The revenue obtained from lactogens plants are thus presented:

recipe 1-

To Cook in the sap of Ficus capensis, fonio (Digitaria exilis) or millet (Pennisetum glaucum) slightly crushed, add water and offer preparation for the nurse who finds abundant rise of his milk after two three days of treatment.

recipe 2-

Add a ground plant Euphorbia hirta of handle, pearl millet (Pennisetum glaucum) crushed beforehand on a grinder and rock salt. Dilute the mixture with water and then drink the milk nurse who sees her climb extensively within hours.

recipe 3 -

Prepare an aqueous extract made from Secamone afzelii with millet (Pennisetum glaucum) crashed out and give to the nurse, there is a milk comes a few days after oral administration.

recipe 4-

Make boil all Euphorbia hirta plants, Jatropha curcas and Cyperus esculentus. The infusion obtained is absorbed by the nurse as a drink. 


\section{International Journal of Science and Research (IJSR) \\ ISSN (Online): 2319-7064}

Index Copernicus Value (2013): 6.14 | Impact Factor (2015): 6.391

4.2Traditional shelf life of shredded fresh and dried plant of Euphorbia hirta and Secamone afzelii at the temperature of $28 \pm 1^{\circ} \mathrm{C}$

Traditional shelf life of plants regrind is evaluated from visuels. The plant shelf life is significantly different depending on the condition of the plant. Dry plant have the longest shelf life regardless of the harvesting site. Thus, Bingerville, shelf life with the dry plant Euphorbia hirta is $90 \pm 4 \mathrm{j}$ and $2 \mathrm{j} \pm 0.0$ for the fresh plant. Bingerville with the dry plant shelf life Secamone afzelii is $90 \pm 5$ days and $3 \pm$ 0.0 for the fresh plant. For Jacqueville, dry plants have longer shelf lives (Euphorbia hirta (dry plant: $90 \pm 2$, fresh plant: $3 \pm 0.0 \mathrm{j})$ ); (Secamone afzelii (dry plant: $90 \pm 3$, fresh plant: $3 \pm 0.0 \mathrm{j}$ )). Unlike plant homogenates retention periods is significant to $5 \%$.

\subsection{Biotolerance test}

\subsubsection{Plasma concentration of glutamic pyruvic transaminase}

Water and extracts of Euphorbia hirta do not significantly affect the plasma concentration of glutamic pyruvic transaminase evaluated in treated rats at $\mathrm{p}>0.05$. Plasma concentrations in rats treated with TGP Euphorbia hirta are $155.25 \pm 51.19 \mathrm{IU} / 1$ for the aqueous extract. However, the plasma concentrations of TGP evaluated in rats treated with aqueous extracts on plant Secamone afzelii are 168.25 \pm 4.19 $\mathrm{IU} / 1$. In rats treated with distilled water, the plasma concentration of TGP is $72.75 \pm 23.12 \mathrm{IU} / 1$. Statistical analysis indicates a significant difference.

\subsubsection{Plasma concentration of transaminases glutamic oxaloacétiques}

The plasma concentrations of transaminases glutamic oxaloacétiques evaluated in rats treated with extracts of plants remain unchanged by the test of Newman-Keuls. Euphorbia hirta (aqueous extract: $161.50 \pm 28.57$ IU / I); (Secamone afzelii (aqueous extract: $165.75 \pm 16.58 \mathrm{IU} / 1$ )).

\subsubsection{Creatinine plasma concentration}

The plasma concentrations of creatinine of the rats treated with distilled water and various plant extracts of Euphorbia hirta and Secamone afzelii not vary significantly at $\mathrm{p}>0.05$. Water: $7.75 \pm 0.95 \mathrm{mg} / 1$; (Euphorbia hirta (aqueous extract: $7.5 \pm 0.57 \mathrm{mg} / 1)$ ); (Secamone afzelii (aqueous extract: $6.5 \pm$ $0.57 \mathrm{mg} / 1)$ ).

\subsubsection{Plasma concentration of urea}

The change in the nature of extracts of Euphorbia hirta and Secamone afzelii and water does not significantly affect the plasma concentration of urea treated rats. The plasma concentrations of urea are: (Euphorbia hirta (aqueous extract: $0.23 \pm 0.02 \mathrm{~g} / \mathrm{1}$ )); (Secamone afzelii (aqueous extract: $0.207 \pm 0.01 \mathrm{~g} / 1)$ ) and distilled water: $0.215 \pm 0.01$ $\mathrm{g} / 1$.

\section{Discussion}

The results obtained from our ethnobotanical survey of traditional healers in southern Ivory Coast show that Euphorbia hirta plants and Secamone afzelii are present on the study sites with the emergence frequency highest among lactogens plants listed (Cyperus esculentus 8\%, Ficus capensis 14\%, Jatropha curcas 2\%, Lactuca taraxacifolia 1\%, Euphorbia hirta 40\%, Secamone afzelii 35\%). 95\% of the 200 believe in the existence of lactogens plants due to their sensitivity to the problem linked to the lactation they seek daily the solution. Also has plants lactogens property are much used because of their relatively cheaper cost. Indeed, Euphorbia hirta is an invasive plant, it is, therefore, naturally available geographically [8]-[14]-[17]-[18] and Secamone afzelii plant cosmopolitan [9] and is widespread in west Africa. Secamone afzelii has extensive ecological adaptation [4]-[12]-[13]-[19]. Medicinal plants including Euphorbia hirta and Secamone afzelii are generally more prevalent in the southern area of the Ivory Coast on the edge of the savannah [24]. This geographical dispersion of medicinal plants of the Ivorian flora has guided us with our choice on the southern resorts of the Côte d'Ivoire such as Anyama, Akoupé, Aboisso, Bingerville, Jacqueville and Abidjan (Abobo, Adjame, Treichville, Marcory and Port Bouet) for the realization of our ethnobotanical survey. According [2], areas of Bingerville and Jacqueville constitute privileged sites Euphorbia hirta harvesting plants and Secamone afzelii. Moreover, the Euphorbia hirta plant was recognized as a plant that can induce lactation in breastfeeding women [15]. Euphorbia hirta and Secamone afzelii grow in hot areas with high rainfall [2]. Also, drying influences the traditional shelf life of Euphorbia hirta of shredded Secamone afzelii. Thus, the study of shredded shelf life of harvested plants to the long dry season, depending on the plant status was conducted. Given the results, (shelf life (dry plants: $90 \pm 2$ day - $90 \pm 5$ days; fresh plants: $2 \pm 0.0 \mathrm{j}$ $3 \pm 0.0 \mathrm{j})$ ), dry plants would offer retention time [25]. Indeed, drying keeps the medicinal plants, to maintain stable flavor and coloring sheets [25].The dry plants would offer high yields extracts. For the use of Euphorbia hirta and Secamone afzelii orally childminding in urban and rural areas, the study of biotolerance important proves due to the presence of toxicity in wild plants [23]. Indeed, the oral administration of plant extracts can generally produce side effects [23] in the body. Hence the need to evaluate the plasma concentration of transaminases glutamic pyruvic and oxaloacétiques, urea and creatinine [21] in female rats. Plasma concentrations of TGP $(72.75 \pm 23.12 \mathrm{UI} / 1)$, creatinine $(7.75 \pm 0.05 \mathrm{mg} / 1)$ in the rats treated with distilled water are consistent with normal values of TGP (35-80UI/1), creatinine $(5-22 \mathrm{mg} / 1)$ [21]. However, plasma concentrations TGO $(209 \pm 55.10 \mathrm{IU} / 1)$ and urea $(0.215 \pm 0.01 \mathrm{~g} / \mathrm{l})$ are similar to the normal values of GOT (159.77-302.23UI/1), urea $(0.17-0.57 \mathrm{~g} / 1)$ [27]. The reference values of agreement could be justified by the credibility of our results. The extracts of Euphorbia hirta used have probably not cause destruction of the membrane of liver and heart cells. Also, they have not led to a decline in glomerular filtration in the kidney level in treated rats. This would justify the consistency of plasma concentrations of TGP, TGO, urea and creatinine [7] in female rats treated with extracts of the plant Euphorbia hirta and those rats treated with distilled water. This matching values to indicate that oral administration of extracts of the plant Euphorbia hirta is not toxic [26] at the heart, liver and kidney in treated rats. This no oral toxicity was also recognized by the Pasteur Institute in Dakar [26]. However, the plasma concentration of glutamic pyruvic transaminase is very high in rats treated with dry aqueous extract of 


\section{International Journal of Science and Research (IJSR) \\ ISSN (Online): 2319-7064}

Index Copernicus Value (2013): 6.14 | Impact Factor (2015): 6.391

Secamone afzelii $(168.25 \pm 4.19 \mathrm{UI} / 1)$ compared to rats treated with distilled water $(72.75 \pm 23.12 \mathrm{UI} / 1)$ and also remain high compared to normal values of TGP (35-80 IU / 1) rats as the work of [21]. The use of aqueous extract of the plant Secamone afzelii orally would have resulted in lysis of the membrane of liver cells and thus cause the release of cellular contents enzyme consisting of TGP in treated rats [19]-[20]-[1]. The reflection of TGP allows to understand the phenomenon of hepatic necrosis. Indeed, the aqueous extract of the plant Secamone afzelii contain phenolic toxic as hydrocyanic acid [20]. The high value of TGP may also be produced by paracetamol overdose in the body orally [10]. The high concentration of TGP evaluated in rats treated with aqueous plant extract Secamone afzelii is rather disturbing insofar Secamone afzelii is used mainly in rural areas as a lactogen plant orally in our ethnobotanical survey. The plant Euphorbia hirta can be used as a lactogen plant, unlike the plant Secamone afzelii which could be side effects pronounced with increasing plasma concentration of TGP in the body.

\section{Conclusion}

The results of ethnobotanical surveys obtained showed that $95 \%$ of 200 respondents believe that healers are lactogens plants can stimulate milk secretion in both urban and rural areas. Euphorbia hirta and Secamone afzelii indicated by healers as key lactogens plants would present more accessible geographically. Therefore, they are sold in the form of boots at relatively low price of 50 to 100 CFA francs. Furthermore, the conservation of dry plants shredded offers conservations potential of 90 day periods. The test bio tolerance associated with the study of power lactogen showed that Euphorbia hirta has a wide possibility of use unlike Secamone afzelii which has side effects made by increasing the plasma concentration glutamic pyruvic transaminase compared to values in rats treated with distilled water.

\section{References}

[1] R.T. Abere and N. Onwukaemed,"Evaluation of the leaves of Secamone afzelii (Schult) K Schum (Asclepiadaceae)," Tropical J. Pharma. Res, 11 (1): 12513, 2012.

[2] E. I. Adjanohoun, "State of evolution of African ethnopharmacology,"Bull. Med. Trad. Phar. 4: 59-63, 1990.

[3] E. I. Adjanohoun and A. L. Ake, "Contribution to the identification of medicinal plants of the Ivory Coast,,"C. R. E. S. Univ. Abidjan, National Center Floristic, $358 \mathrm{p}, 1979$.

[4] A. L. Ake, "Flora of Ivory Coast: systematic catalog, biography and ecology, systematic botany,"boissiera, 58. Memory (II), and Ed. Conservatoires Jard. Bot., Geneva, 401p, 2002.

[5] A. Alison,"Laboratory animals: The Renaissance rat. Nature," 428 (6982): 464-466, 2004.

[6] B. Belanger and M. C. Guitry,"Breastfeeding promotion mother and children side: RHARD on site consultation, 9 p. 3, 1989.
[7] G. Bigaignon and J. Ninane,"Laboratory tests and drugs; In: Clinical pharmacology, therapeutic bases," Exp. Sci. French. Plasma volume expansion, p.1295-1299, 1988.

[8] M. Braun, H.M. Burgstaller and A. W.H. Hamdoun, "Common weeds of Central Sudan. GTZ, Josef Margraf Verlag ed. Sci. Book, Weikersheim, Germany, 329p, 1991.

[9] L. Bray, “In: The Truffaut,"Illutrated Practical Encyclopedia of the garden, Paris, ed. Patrick Mioulane. Pub. Larousse: p.76-77, 2005.

[10] P. Demoly,"The paracetamol and non-steroidal antiinflammatory drugs," Allergies encyclopedias. Ann. Allergy Asthma Immunol., 90: 342-347, 2007.

[11]I. Doumbiba,"Toxicity and biotolerance of Mitracarpus scaber and Mareya micranta in mice and rabbits," Doctoral thesis at the University of Cocody-Abidjan, 207 p, 2008.

[12] M. C. Gaw; D. M. VAN Der, J. N. Ellof, "In vitro anthelmintic, antibacterial and cytotoxic effects of extracts from plant used in South African," ethno veterinary medicine. Veterin. J., 173 (2): 366-372, 2007.

[13] M. C. Gaw and. J. N. Eloff, "Ethnoveterinary use of southern Africa Plants and scientific assessment of Their medicinal properties,"J. Ethnopharm, 119. 559-574, 2008.

[14] L. G. Holm, D. L. Plucknett, H. J. V. Pancho,"The World's Worst Weeds: Distribution and Biology," EastWest Center, University of Hawaii Press, Honolulu, $609 \mathrm{p}, 1977$.

[15] L. M. Houdebine, L. Sawadogo and H. Sepehri, "Study of the lactogenic action of beer, " Exp. Sci. French, 147: $1-4,1990$.

[16] O. Houot, "In Interperation of Clinical Laboratory Tests," Biomedical Publications. Edited by G. Siest, Henry J., Schiele F, 220-234, 1985.

[17] G. W. Ivens, "East African Weeds and Their Control," Oxford University Press, Nairobi, Kenya, 289p, 1989.

[18] G. W. Ivens and J. K. M.Egunjobi,"West African Weeds," Oxford Univ. Press, Ibadan, Nigeria, 255P, 1978.

[19] V. A. Kemeuze, "Secamone afzelii (Schult.) K. Schum Schmelzer, G. H and Gurib-Fakim, A Medicinal plants 2," Editors. Prota., 11 (2), 2010.

[20]L. Lagnika, Anagoand Sanni, “A Screening for antibacterial, antioxidant activity and toxicity of Some medicinal plants used in folkloric medicine Benin," J. Med. Plant Res, (515): 773-777, 2011.

[21] J. Laroche, P. Fabiani, F. Rousselet, "Toxicological expertise drugs," Ed. Masson, Paris, 367 p, Blood of Laboratory rats. Sci. For lactogens plants.Trad. Med, 1986.

[22] R. Leonard and Z. Ruben, "Hematology reference values for peripheral blood of Laboratory rats," Research Animal Res, 36 (3). 277-281,1986.

[23] D. Maiga, S. R. Fanes, N. B. S. Paulsen and B. Cisse,"A survey of toxic plants on the market in the district of Bamako, Mali, traditional knowledge compared with a literature search of modern pharmacology and toxicology,"Ethnopharm. 96: 183-193, 2005.

[24] K. N'Guessan, "Contribution to ethnobotanical study in krobou countries (Republic of Ivory Cost)," Exp. Sci. French Doctorate 3rd cycle thesis at the University of Cocody-Abidjan. 273p,1995. 


\section{International Journal of Science and Research (IJSR) \\ ISSN (Online): 2319-7064}

Index Copernicus Value (2013): 6.14 | Impact Factor (2015): 6.391

[25] G. B. Noumi, Y. M, C. B. Njouokan and C. Njine Kapseu,"Effect of drying on the yield and quality of the oil extracted from the pulp of safou, Tropicultura," 29 (3): 138-142, 2011.

[26]E. Poulet, "A medicinal plant of Upper Volta. The Malnommée (notes voltaic and documents)," 6 (1): 2530, 1992.

[27] L. J. Tehoua, Y. Datte, A. M.Offoumou, “Alcoholization chronic rats (Rattus norvegicus) of Wistar strain a traditional brandy produced in Ivory Cost (koutoukou), " J. Applied Biosciences, 41: 2772-2779, 2001.

\section{Author Profile}

Adepo yapo prosper received degrees of Doctor of Unique option Biotechnologies University Food Science Felix Houphouët-Boigny Ivory Coast 20022012. He remained in the Laboratory of Biochemistry and Food Sciences during all this research for obtaining the Diploma of Advanced Studies in Food Biotechnology and $\mathrm{PhD}$ Unique listed above. It is now Lecturer at the Felix Houphouët-Boigny University Ivory Coast. 